Sergey Nikolaevich BOLSHAKOV

Pushkin Leningrad State University, Russia

snbolshakov@gmail.com

https://orcid.org/0000-0002-4858-8216

https://doi.org/10.34739/dsd.2021.02.02

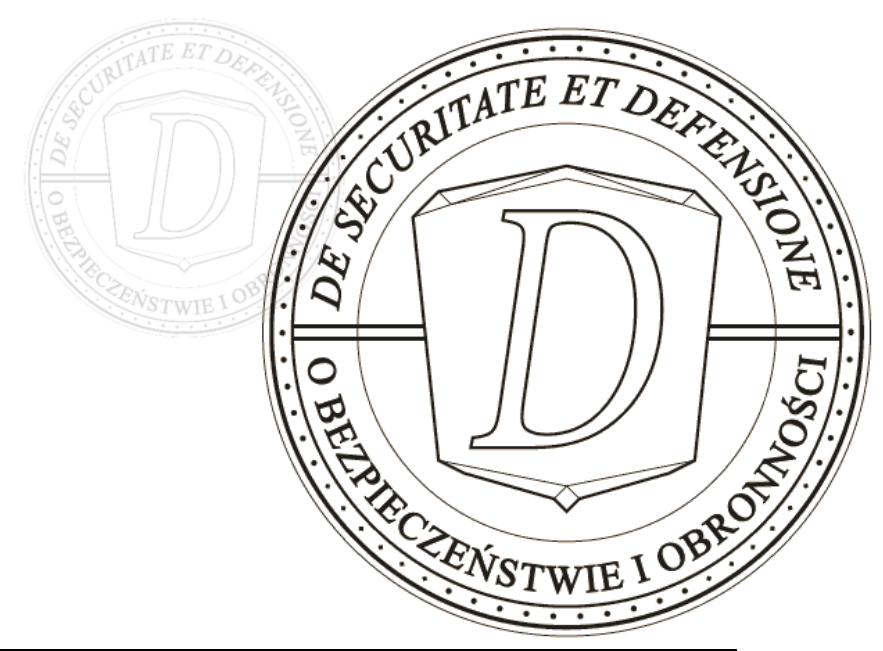

\title{
НАПРАВЛЕНИЯ РЕАЛИЗАЦИИ СТРАТЕГИИ \\ НАЦИОНАЛЬНОЙ БЕЗОПАСНОСТИ СТРАН \\ БАЛТИЙСКОГО РЕГИОНА
}

\begin{abstract}
Аннотация: В статье анализируется стратегия и принципы построения стратегии национальной безопасности Российской Федерации, рассматриваются приоритеты обеспечения национальной безопасности. Доктрины в сфере безопасности направлены на безопасность в сфере военной, политической, информационной обстановки. В статье выделены приоритетные задачи в области национальной обороны Российской Федерации. В обзоре проанализированы стратегии комплексной безопасности стран Балтийского региона - Эстонии, Литвы, Латвии; анализируется доктрина «тотальной обороны» Эстонии, порядок и формы ее реализации. Анализируется эффективность доктрины «тотальной обороны» Эстонии, констатируется, что страны Прибалтики рассматривают различные варианты по повышению безопасности, концепции “тотальной обороны”, основывается на защите позиции нейтралитета, оборонная политика стран основывается на сотрудничестве с крупными европейскими и региональными странами (Финляндия, Швеция, Польша). В статье констатируется, что военная безопасность стран связывается с необходимостью углубления сотрудничества с НАТО. Анализируется доктрина территориальной обороны Эстонии, Латвии, Литвы, направления оборонной политики и территориальной безопасности.
\end{abstract}

Ключевые слова: Балтийского Региона, военная политика, стратегия, оборона, внешняя политика, силы обороны

\section{DIRECTIONS FOR IMPLEMENTING THE NATIONAL SECURITY STRATEGY OF THE BALTIC REGION}

ABSTRACT: The article analyzes the strategy and principles of building the national security strategy of the Russian Federation, considers the priorities of ensuring national security. Security doctrines are aimed at security in the military, political, and informational environment. The article highlights the priority tasks in the field of national defense of the Russian Federation. The review analyzes the integrated security strategies of the countries of the Baltic region - Estonia, Lithuania, Latvia; analyzes the effectiveness of the doctrine of "total defense" of Estonia, the procedure and forms of its implementation. It is stated that the Baltic countries are considering various options to improve security, the concept of "total defense", is based on the protection of the position of neutrality, the defense policy of the countries is based on cooperation with large European and regional countries (Finland, Sweden, Poland). The article states that the military security of countries is 
associated with the need to deepen cooperation with NATO. The doctrine of territorial defense of Estonia, Latvia, Lithuania, directions of defense policy and territorial security is analyzed.

KEYWORDS: Baltic Region, military policy, strategy, defense, foreign policy, defense forces

\section{ВВЕДЕНИЕ - АКТУАЛЬНОСТЬ ИССЛЕДОВАНИЯ СТРАТЕГИЙ НАЦИОНАЛЬНОЙ БЕЗОПАСНОСТИ}

Принятая стратегия национальной безопасности России является не только документом стратегического планирования, но и инструментом государственной политики по реализации задач в сфере обеспечения национальной безопасности на долгосрочную перспективу. Приоритеты стратегии провозглашают соблюдение и защиту прав и свобод человека и гражданина, повышение благосостояния общества. Важным видится то, что в стратегии национальной безопасности зафиксировано понятие обеспечение национальной безопасности посредством взаимодействия органами публичной власти с институтами гражданского общества, на основе организации политических и правовых мер по противодействию угрозам национальной безопасности.

Принятая стратегия национальной безопасности исходит из рисков и возможного ущерба исходящего от стран Запада, что является по мнению авторов стратегии причины нестабильности в мире. Данная стратегия является ответом на возрастающую геополитическую напряженность, рост экстремистских настроений и межгосударственных противоречий. В стратегии прослеживается линия по поиску внутренних и внешних врагов, которые по мысли авторов, стремятся к разрушению экономики страны, традиционных ценностей ${ }^{1}$.

Целью статьи является анализ подходов к формированию приоритетов национальной безопасности и оборонной политики стран Балтийского региона, на примере анализа официальных документов России и Прибалтийских стран.

Актуальность вызвана тем, что в значительный период с середины 2000-х годов наблюдается определенное охлаждение и враждебность взаимоотношений между РФ и группой Балтийских стран. Во взаимоотношениях негативным фоном остаются военные конфликты на территории Грузии, Украины. Страны Прибалтики естественным образом пытаются демпфировать чувство страха, неуверенности и риска посредством активизации участия в процессах формирования общей политики безопасности стран Европейского Союза, объединения НАТО. В масс-медиа стран постоянно ведется дискуссия о задачах обеспечения безопасности и необходимости укрепления обороны.

В стратегии национальной безопасности России подчёркивается, что имеет место распространение практики недобросовестной конкуренции, использование

\footnotetext{
${ }^{1}$ Стратегия национальной безопасности РФ [Strategiya natsionalnoj bezopasnosti], scrf.gov.ru, scrf.gov.ru (25.11.2021).
} 
протекционистских мер для оказания экономического давления ${ }^{2}$. Отдельной строкой в стратегии национальной безопасности декларируется проблема контроля за транспортными маршрутами Арктики.

Изменение мировой политики, международной повестки для России видеться не только новым вызовом для мироустройства, но и коридором возможностей для долгосрочного развития и позиционирования России. Долгосрочными интересами в данной стратегии провозглашается развитие безопасного информационного пространства, новое технологическое развитие экономики, адаптация окружающей среды к изменениям климата.

Сфере обороны страны и военная политическая обстановка характеризуется обострением противостояний между ведущими странами за сферы влияния, подчёркивается возрастание военной силы как инструмента достижения геополитических целей субъектами международных отношений. Приоритетными задачами в сфере обороны является не просто совершенствование планирования мер по мобилизационной подготовке, но и своевременный учёт тенденций изменение характера современных войн и вооружённых конфликтов, необходимость совершенствования мер технологической независимости оборонно-промышленного комплекса России 3 .

Достижения комплекса стратегических задач в сфере безопасности видеться авторами через повышение доверия граждан к институтам власти и развитие институтов гражданского общества, предупреждение правонарушений с использованием информационных коммуникационных технологий и пр.

\section{ОСНОВНЫЕ ТЕОРЕТИЧЕСКИЕ И ПРАКТИЧЕСКИЕ ПОЛОЖЕНИЯ}

Утвержденные Президентом Российской Федерации основы государственной политики в области международной информационной безопасности представляют собой комплекс мер направленных на формирование системы в международной информационной безопасности с учётом национальных интересов Российской Федерации ${ }^{4}$. Данные направления государственной политики направлены не только на продвижение на международной арене российских подходов в сфере международной информационной безопасности, но и содействие созданию международно-правовых механизмов по предотвращению межгосударственных новых конфликтов в информационной сфере. Основными направлениями государственной политики видеться не просто продвижение национальных стандартов Российской Федерации в области информационной безопасности, но и совершенствование механизма участия

\footnotetext{
${ }^{2}$ Ibidem.

${ }^{3}$ Военная доктрина РФ [Voennaya doktrina FR], scrf.gov.ru (25.11.2021).

${ }^{4}$ Доктрина информаџионной безопасности РФ, Совет Безопасности Российской Федераџии ) [Doktrina informatsionnoj bezopasnosti RF, Sovet Bezopasnosti Rossijskoj Federatsii], scrf.gov.ru (25.11.2021). 
представителей российского экспертного и научного сообщества в продвижении инициатив по формированию системы международной информационной безопасности.

Отдельное место в государственной политике занимает совершенствование механизма обмен информацией в сфере расследования преступлений в отношении компьютерной информации, информационного мошенничества, кибербезопасности.

Принятая в 2014 году военная доктрина Российской Федерации является стратегическим документом описывающим положение военной политики и военноэкономического обеспечения обороны государства на основе оценки военных опасностей и угроз для страны. Военная доктрина, как стратегический документ, основывается на оценке «Морской доктрины России» и «Стратегии развития арктической зоны России», данные документы действовали на период до 2020 года 5 .

В доктрине также поддерживается концепция региональных конфликтов, фиксируется сохранение глобальных тенденций к силовому разрешению региональных конфликтов и слабости существующей архитектуры международной безопасности, которая не гарантирует равную безопасность всех государств.

В военной доктрине выделены основные военные опасности, такие как развертывание систем стратегической противоракетной обороны, наращивание воинских контингентов иностранных государств и групп государств на сопредельных территориях с Россией, дестабилизация обстановки в отдельных государствах и регионах. В «Военный доктрине России» отдельное место уделяется внутренним военным опасностям, таким как насильственное изменение конституционного строя, дестабилизация политической и социальной ситуации в стране, дезорганизация военных объектов и информационной инфраструктуры.

Сложным вопросом в области безопасности для России является активность оборонной политики Литовской Республики в ее сотрудничестве с НАТО, т.к. это в определенном смысле осложняет процесс транспортно-логистического обеспечения и передвижения грузов и вооружений в Калининградской области которая является «заложником ситуации». Калининградская область находится в окружении стран НАТО, что является фактором снижения национальной безопасности. Раздражающим фактором для внешней политики России является размещение в странах Балтии военно-воздушной базы НАТО и наращивание сил для патрулирования воздушных границ с Россией, сокращается время подлета военных самолетов НАТО к Санкт-Петербургу и Москве до 30 минут. Все это является основанием для перестраивания приоритетов оборонной политики и ее сопровождения.

${ }^{5}$ Совет Безопасности... [Sovet Bezopasnosti...], op.cit. 


\section{Оценка национальных стратегий безопасности: ресурсы и возможности}

Как видно из проведённого анализа особое значение в государственных стратегиях и доктринах России занимает поиск возможных решений на вызовы меняющейся геополитической среды. Важным видится поиск механизма по снижению рисков и вызовов в зоне приграничных государств, в том числе государств Балтийского региона.

В последнее время все больше обостряется политическая риторика национальных лидеров, как России, так и Белоруссии, последняя высказала желание разместить на своей территории ядерное оружие России. Подобное политическое нагнетание обстановки и агрессивная риторика СМИ естественным образом вызывает обеспокоенность стран не только Прибалтики, но и всего Европейского Союза. Реакцией на обеспокоенность данных стран является выработка совместных действий в рамках военно-политического союза НАТО ${ }^{6}$.

В странах Прибалтики (Эстонии Литвы и Латвии) рассматриваются различные варианты по повышению безопасности, через возрождение концепции „тотальной обороны”. Данная концепция основывается на защите позиции нейтралитета как необходимости разрешения вопросов обороны, посредством сотрудничества с крупными европейскими и региональными странами (Финляндия-Швеция) ${ }^{7}$. Следует отметить, что в современных международных отношениях риски и угрозы диверсифицированы и возникают в различных регионах мира. Страны Прибалтики активно участвуют в разрешении подобных кризисов международной политической системы, посредством экспедиционных, миротворческих операций. Стратегия обороны Литвы несколько отличается от позиции Эстонии и Латвии, так как изначально национальная дискуссия по поиску подходящей модели защиты государства Литва основывалась на шведской модели нейтралитета, и тем не менее важная позиция в отношении военной безопасности страны связывается с потенциалом НАТО. Данный стратегический выбор привёл к определённому варианту стратегии оборонной политики, который соответствует стандартным и процедурам НАТО. Литва и Латвия активно участвуют в коалиции с США в боевых действиях в составе НАТО на основе 5 статьи Североатлантического договора. Оборонная политика Эстонии основывается на более осторожном подходе, является более близкой к финскому архетипу обороны и страна выборочно участвует в операциях $\mathrm{HATO}^{8}$.

\footnotetext{
${ }^{6}$ NATO, Supreme Headquarters Allied Power Europe, Allied Command Operations Comprehensive Operations Planning Directive COPD Interim v 1.0, 2010, https://info.publicintelligence.net/NATO-COPD.pdf (27.11.2021).

${ }^{7}$ A. Maskaliunaite, Editorial Introduction: Special Issue on Understanding of Total Defence in the Baltic Countries, ,Journal on Baltic Security” 6(2)/2020, p. 1-2.

${ }^{8} \mathrm{~V}$. Veebel and others, Territorial Defence, Comprehensive Defence and Total Defence: Meanings and Differences in the Estonian Defence Force, "Journal on Baltic Security" 6(2)/2020, p. 1-13. 
Военная операция на территории Украины существенно трансформировала стратегическое восприятие ситуации безопасности в Балтийском регионе, обеспокоенность стран вызывает появление новых форм гибридной войны. Все это позволило странам Балтии выявить недостатки существующих механизмов обороны и сформировать новые требования к защите страны 9 . Всё большее значение для стран приобретает концепция «тотальной защиты», которая обеспечивает определенную преемственность и эволюционность концепции обороны. Эстония сохраняет призыв на военную службу полагаясь на значительные силы резервистов в случае военного конфликта, добровольческие отряды „Кайтселиит”, что является важным фактором поддержания обороноспособности страны. При этом возникают определённые проблемы в дисбалансе между профессиональными вооруженными силами и добровольческими формированиями. Некоторые авторы, К. Атманте, отмечают отсутствие координации между эстонскими и латвийскими подразделениями территориальной обороны, что является недостатком в случае вооружённых конфликтов ${ }^{10}$. Латвия сохраняет профессиональную армию, внедряет систему соответствующего обучения резервистов среди молодёжи, что позволяет компенсировать риски отсутствия гражданских резервистов и отмену воинской повинности.

В статье Статкуса отмечается литовское понимание тотальной защиты, которая сосредотачивается на понимании самостоятельного реагирования страны в случае военной ситуации, в условиях растущей конкуренции глобальных держав ${ }^{11}$. Всё это требует переосмысления стратегии обороны и сдерживания, которую разрабатывают страны Балтии, самостоятельности формирования общей, кооперативной системы безопасности ${ }^{12}$. Вышеуказанное является важным в условиях гибридной войны, когда затрудняется возможный адекватный военный ответ, базирующийся исключительно на вооруженных силах. В военных доктринах стран Прибалтики отмечается важность энергетической безопасности, защиты киберпространства, необходимость разработки информационных стратегий, противостоящих негативным нарративам ${ }^{13}$.

Оборонная политика и военная доктрина считается стратегической задачей национального консенсуса Эстонии. Защита территории страны и доктрина тотальной обороны зависит от множества культурных и языковых факторов. Поддержка оборонной

\footnotetext{
9 D. Šlekys, Nauji / seni gynybos politikos namu darbai, LRT, 2020, https://www.lrt.lt/naujienos/ nuomones/3/1281401/deividas-slekys-nauji-seni-gynybos-politikos-namu-darbai?fbclid=IwAR2uJFnMQc7y0U3QBUSb4npivpp3hipdl Dvu_XZgN3gjYKBns4prt1XazmE (01.11.2021).

${ }^{10} \mathrm{~K}$. Atmante, Comprehensive defence in Latvia - rebranding state defence and call for society's involvement, "Journal on Baltic Security" 6(2)/2020, p. 1-15.

${ }^{11}$ N. Statkus, K. Paulauskas, Foreign Policy of Lithuania: Linking Theory to Practice, "Lithuanian Foreign Policy Review" 17/2006, p. 41-82.

${ }^{12}$ Latvian National Guard 2019, https://www.zs.mil.lv/en (21.11.2021).

${ }^{13}$ S.J. Flanagan (et al.), Deterring Russian Aggression in the Baltic States through Resilience and Resistance, RAND Corporation 2019, https://www.rand.org/pubs/research_reports/RR2779.html (26.11.2021).
} 
политики Эстонии в значительной степени находится под влиянием образовательных традиций в военной сфере и союзнических отношений. Военная доктрина Эстонии опирается на союзнические отношения и активное участие в блоке НАТО, что способствует поддержке национальной обороны и является элементом сдерживания. Военная доктрина Эстонии основана на принципе солидарности. Страна имеет возможность принимать союзные войска, что для местного населения является определённой гарантией безопасности страны ${ }^{14}$. При интегрированном сдерживании противника и обороне НАТО возможности местной территориальной обороны для Эстонии играют решающую роль.

В период с 2012 по 2020 год система государственной обороны была основана на разделении территориальной обороны, осуществляемой Министерством обороны Эстонии, проводилась активная деятельность Вооруженных сил при поддержке пехотных бригад и сил НАТО, в кооперации с многонациональными боевыми группами из Эстонии, Латвии Литвы и Польши, при объединённом командовании Великобритании, Канады, ФРГ и США ${ }^{15}$.

В учебнике по обороне определение тотальной обороны заключается в следующем: это постоянная готовность гражданских структур государства, местного самоуправления, сил обороны страны, а также интеллектуального, физического, экономического и иного потенциала всей нации для разрешения кризиса, и скоординированных совместных действий по предотвращению и сдерживанию угрозы нападения для «выживания нации» ${ }^{16}$. Доктрина тотальной обороны Эстонии трансформировалась в пользу интегрированной обороны НАТО и политики сдерживания. Оборонная политика Эстонии основывается на эволюции немецких и советских концепций обороны и Эстонию можно рассматривать как яркий пример оборонной политики стран Северной Европы (Финляндия, Швеция, Норвегия). Доктрина тотальной обороны была заявлена Эстонией в 2001 году как „Стратегия военной обороны”. Под тотальной защитой понималось постоянная психологическая, физическая, экономическая и другие виды готовности государства и муниципальных учреждений, сил обороны и всего общество для разрешения кризиса ${ }^{17}$. Основная идея тотальной обороны - это мобилизация ресурсов страны для защиты государства во время кризиса и войны. Сам термин „тотальная защита” является отражением конфликтов прошлого, основанных на географии и ограниченности военных действий географией Прибалтийского региона.

\footnotetext{
${ }^{14}$ Estonian Ministry of Defence, Yearbook of Estonian Ministry of Defence 2008, Milterm: Comprehensive Approach. Yearbook 2008/2009, Ministry of Foreign Affairs, vm.ee (26.11.2021).

${ }^{15}$ V. Veebel and others, Territorial Defence, Comprehensive Defence and Total Defence...op.cit.

16 Ibidem, p. 7.

${ }^{17}$ Estonian Ministry of Defence, Yearbook ...op. cit.
} 
Современные гибридные конфликты свидетельствуют о невозможности провести четкое разграничение между миром, конфликтами и войной. Доктрина тотальной обороны Эстонии является комплексной концепцией всеобъемлющей защиты. Оборонная политика Эстонии, основываясь на сдерживании, рассматривается как основа политики, участие в НАТО характеризуется как средство обеспечения скоординированного ответа на возможные кризисы с участием всех заинтересованных сторон. В новой «Стратегической концепции НАТО», принятой на Лиссабонском саммите в ноябре 2010 г., подчеркивается, что эффективная оборонная политика требует комплексного подхода, включающего политические, гражданские и военные инструменты. Военные средства сдерживания и обороны хоть и необходимы, но их недостаточно для решения сложных задач в сфере безопасности стоящих перед странами членами НАТО. Концепция национальной безопасности Эстонии, принятая в 2017 году, основывается на принципах устойчивости, полагается на потенциал органов государственного управления и всего эстонского общества. Данный интегрированный подход является концептуальным импортом принятым всем эстонским обществом. Идея национальной обороны, которая является совместной задачей всего общества, широко поддерживается в Эстонии. Как показывает опрос общественного мнения (март 2018) - 78\% респондентов поддерживают эту точку зрения и только 6\% респондентов против данной концепции ${ }^{18}$. Это показывает, что ожидания эстонцев в отношении выбора всеобъемлющей модели национальной обороны очень высоки. Таким образом демонстрируется высокий уровень сопротивляемости вызову основной массы населения.

Для военной доктрины Эстонии важной составляющей является военногражданское сотрудничество. Комплексность подхода в выборе стратегии национальной обороны и механизма её обеспечения охватывает не только военную деятельность, но и предполагает сплочённую координацию внутренней безопасности страны.

Территориальная оборона Эстонии основывается на следующих принципах: a) силы обороны подразделяются на две части, которые составляют общую часть обороны и территориальные силы обороны; б) территория страны подразделяется на военные округа; в) на базе военно-территориальных формирований управление организовано таким образом, чтобы предотвратить возможные кризисы, когда возможно разрушение единой системы управления обороной, или когда замедляется помощь НАТО $^{19}$. Здесь можно отметить, что концепция территориальной обороны отражает логику концепции тотальной обороны. Если последняя ориентирована на театр военных действий, то территориальная оборона может рассматриваться как практический способ ее применения. Концепция создания сил национальной обороны - это естественное

\footnotetext{
18 J. Kivirähk, Public Opinion and National Defence, Ministry of Defence, Tallin 2018, https://kaitseministeerium.ee/sites/default/files/elfinder/article_files/public_opinion_and_national_defence_2018_october_0.pdf (26.11.2021).

${ }^{19}$ National Defence Action Plan 2019-2022, Estonian Ministry of Defence, 2018, http://www.kaitseministeerium.ee/en/objectives-activities/defence-planning/national-defence-action-plan-2019-2022 (27.11.2021).
} 
право государства и его основная функция. Теоретически территориальную оборону можно подразделить на 3 основные категории: а) первая категория основывается на модели вооруженных сил готовых к решению оперативных боевых задач или быть постоянно готовыми отправиться за границу для выполнения оперативных задач; б) вторая категория представлена небольшой группой государств, которые интегрируют усилия для защиты, облегчая задачу мобилизации регулярных военных сил и их оперативного развертывания и маневра (Эстония, Литва, Латвия, Норвегия, Дания, Бельгия); в) к третьей категории относятся нейтральные страны с широким спектром задач, в т.ч. ведение внутренних военных действий в случае оккупации (Финляндия, Швеция Швейцария).

Некоторым авторам эффективным видится способ ослабления агрессора при проведении гибридных операций через правильно организованную территориальную оборону ${ }^{20}$.

Единственный способ ослабить эффективность агрессоров при проведении гибридных операций - это грамотно развитая система территориальной обороны, потому что формирование сил территориальной обороны может быть оперативно развернутым на местном уровне и действовать на основе принципов единства командования при сохранении определенной автономии проведения операций ${ }^{21}$.

Создание и функционирование сил территориальной обороны, на основе добровольности, сознательно стимулирует мотивацию граждан к готовности посвятить свою судьбу национальной обороне, что поддерживается в Эстонии высоким уровнем патриотизма ${ }^{22}$. Данный фактор особенно важен с точки зрения гибридных угроз, рисков и возможных конфликтов.

Авторы современной доктрины обороны Эстонии подчеркивают важность вложений в повышении боевой мощи армии, необходимости проведения более интенсивных учений с регулярными военными подразделениями вооруженных сил на основе отработки действий обороны современных систем вооружения, противотанковых средств, с учетом сил потенциального противника.

Безусловно добровольность территориальных сил самообороны снижает требования к боевой мощи этих подразделений, что несопоставимо с качеством подготовки регулярных вооруженных сил. Профессиональная подготовка регулярных армий требует соответствующего дополнительного профессионального обучения, что важно, если учения проводятся с привлечением вооруженных групп армии стран-

${ }^{20}$ T. Jermalavičius and others, Comprehensive Security and Integrated Defence: Challenges of implementing whole- of-government and whole-of-society approaches, (ICDS Report), International Centre for Defence Studies, https:// www.digar.ee/arhiiv/et/download/200632 (10.12.2021).

${ }^{21}$ R. Jakubczak, Wojska Obrony Terytorialnej w sztuce wojennej, „Ante Portas - Studia nad Bezpieczeństwem” № 2(7)/2016, s. 42.

22 Strategy of State Defence, Estonian Ministry of Defence, 2010, http://www.kaitseministeerium.ee/sites/default/files/elfinder/article_files/riigikaitse_strateegia_2010_0.pdf (27.11.2021). 
союзников (Швеция, ФРГ, Дания, Латвия и т.п.). Это ставит вопрос о необходимости прорабатывать особую тактику и способность отрабатывать операции по оперативному развертыванию сил обороны на местности.

М. Клеммесен в своей статье отмечает, что стратегия территориальной обороны не является оптимальным вариантом национальной обороны. По его мнению, более эффективна стратегия по сдерживанию агрессора до момента его проникновения на территорию страны, но подобный вариант не возможен, если небольшие национальные армии обороны сталкиваются с более сильными противниками ${ }^{23}$.

Также А. Лаанеотс пишет, что в Эстонии при оценке оборонных сценариев было принято взвешенное решение о создании сил, которые не только могли бы защищать суверенитет, но и оказывать постоянное сопротивление во время длительного вооруженного конфликта ${ }^{24}$. Аналогичный подход при разработке стратегии обороны применялся в Литве и Латвии.

Стратегия обороны Эстонии реализуется на основе подхода «тотальной обороны», наличия обязательной, постоянно-действующей армии и резервной армии. Латвия же ориентирует себя на стратегию исключительно профессиональной армии со значительно меньшим количеством вспомогательного персонала, Литва использует смешанную систему. Эстонская и Латвийская оборонные стратегии представляют собой интегрированную модель ${ }^{25}$, представляющую противоположные варианты с точки зрения территориальной защиты, тогда как Литва представляет собой компромиссный вариант.

Эстония использует смешанную модель наличия профессионального военного контингента, наличие призывной армии и резервистов. Профессиональный армейский контингент насчитывает около 3400 военнослужащих, относящихся к профессиональным военнослужащим по состоянию на 2019 год. Данный контингент состоит только из профессиональных военных, этот батальон входит в командование 1й пехотной бригады, которая представляет собой основу сухопутных войск Эстонии ${ }^{26}$.

После успешных реформ и переговоров о вступлении, в 2004 году к НАТО присоединились Эстония и другие страны Балтии. НАТО постепенно трансформировалась из организации приверженной принципу коллективной защиты в многозадачный стратегический орган управления, занимающийся вопросами, выходящими за рамки коллективной защиты, например, антитеррористическая деятельность, миротворческие миссии и кризисное управление. Членство в НАТО и Европейском Союзе стали

\footnotetext{
${ }^{23}$ M. Clemmesen, Territorial Defence in Baltic Defence College, “The Baltic Defence Review” №3/2000, p.14

${ }^{24}$ A. Laaneots, The Defence League and Defence Districts, “The Baltic Defence Review” №3/2000, p. 92.

${ }^{25}$ R. Graube, The Latvian Armed Forces Today, "Nato's Nations and Partners for Peace” Special Issue/1999, pp. 63-68.

${ }^{26}$ Strategy of State Defence, Estonian...op.cit.
} 
приоритетами внешней политики стран Балтии ${ }^{27}$. В контексте приоритетов внешней политики всех стран Балтии речь идет не только об этих двух международных организациях, но и о стратегическом партнерстве с ними, тесном сотрудничестве с США и Великобританией, поддержке трансатлантических связей. Все это сыграло важную роль в понимании возможностей сдерживания угроз в отношении стран Балтии, особенно со стороны России.

Для военной доктрины Эстонии важным фактором является задействование резервистов и гражданских лиц, как потенциала сил самообороны. Например, дальнейшее развитие гражданского союза „Лиги защиты Эстонии” продолжается и в соответствии с «Национальным планом действий по обороне на 2019-2022 годы», финансирование позволит обеспечить «оснащение 6 новых территориальных организаций обороны», к 2022 году будут организованы «6 легких пехотных рот, которые будут добавлены к имеющимся пехотным ротам. Будут созданы 4 батальона территориальной оборонной структуры Союза обороны Эстонии». Эти подразделения являются частью оборонной структуры военного времени, но будут укомплектованы и обучены «Союзом обороны Эстонии». Увеличение финансирования позволит продолжить и совершенствовать патриотическое воспитание, провести дополнительный набор для удовлетворения потребностей большего количества гражданского призыва. Обучение будет поддерживаться школой Союза обороны Эстонии, в которой есть соответствующие кадры и инфраструктура ${ }^{28}$.

В августе и сентябре 2020 года среди эстонских офицеров, обучающихся в Балтийском оборонном колледже и в магистратуре Эстонской военной академии было проведено социологическое исследование относительно вопросов территориальной обороны и тотальной защиты. Результаты интервьюирования в фокус-группах не позволили однозначно ответить на вопрос, равнозначна ли для респондентов позиция защиты отечества и территориальная оборона? Столь же неоднозначными были ответы на вопрос о том, какой первостепенный объект должен защищать военный и резервист (включая «Лигу обороны Эстонии»): это земля, люди, стратегические объекты, логистические центры (аэродромы и гавани для кораблей) или государственные учреждения? Однако важность фактора территориальной защиты со стороны «Лиги Обороны», как способности дополнительно привлекать ресурсы и защищать те или иные объекты регулярными пехотными бригадами за пределами их зоны дислокации (в пределах 100 квадратных километров на бригаду), по мнению респондентов не представляется возможным ${ }^{29}$.

\footnotetext{
${ }^{27}$ P. Szymański, The Baltic states' Territorial Defence Forces in the face of hybrid threats, Commentaries OSW. Centre for Eastern Studies (OSW), Warsaw № 165, 19 March/2015, p. 1-6, https://www.osw.waw.pl/en/publikacje/osw-commentary/2015-03-20/baltic-states-territorial-defence-forces-face-hybrid-threats (27.11.2021).

${ }^{28}$ V. Veebel and others, Territorial Defence, Comprehensive Defence and Total Defence...op.cit.

${ }^{29}$ Estonian Defence League, 2019, http://www.kaitseliit.ee/en/edl (05.11.2021).
} 
По мнению респондентов, деятельность по территориальной обороне больше связана со сдерживанием сил противника, тогда как обычная военная деятельность рассматривается как условие задержки противника и защиты жизненно важных пунктов до прибытия подкреплений НАТО.

Респонденты также подчеркнули, что предпочли бы сражения в сельской или лесной местности и избегали боестолкновений в городах.

Центральный вопрос заключался в том, насколько будет штаб дивизии НАТО или штаб Северо-Восточного корпуса НАТО разделять и понимать цели и приоритеты территориальной обороны Эстонии или будут продвигать свои собственные цели. По мнению респондентов, наиболее предпочтительным подходом является комплексная защита, а не тотальная война. Вариант территориальной защиты рассматривается как сложно-реализуемый в условиях дефицита ресурсов, а также по той причине, что партизанам могут не понадобиться генералы для реализации их видения стратегии тотальной обороны.

Респондентами подчеркивалось, что к провокациям на сухопутной границе следует относиться гораздо серьезнее, чем к провокациям и систематическим нарушениям воздушного пространства, невозможно точно узнать нарушена ли морская граница. Зависимость от ограниченных ресурсов страны нелегко принять, поскольку отсутствие должной защиты береговой линии делает территориальную оборону уязвимой. В связи с ограниченными возможностями вполне естественно, что победа и успешная оборона с использованием модели тотальной защиты практически невозможны, но это даст временной выигрыш с надеждой на то, что вооруженные подкрепления союзников прибудут раньше, чем у страны закончатся собственные ресурсы обороны ${ }^{30}$.

Интегрированная концепция обороны стран Балтии считается необходимой для обеспечения эффективности территориальной обороны Эстонии. В восприятии концепции сказывается разрыв поколений среди высших должностных лиц армии, именно их позиция является критической переменной; старшее поколение офицеров не высказывает желание сотрудничать в рамках интегрированной обороны Балтии и предпочитает сосредоточиться на местной территориальной защите с отдельными элементами тотальной защиты.

Проблемные вопросы оценки оборонной политики и политики безопасности легли в основу интервью с фокус-группами, проведенных в ходе некоторых исследований. Как показали интервью в фокус-группах, возникают две центральные проблемы территориальной обороны как составляющей национальной обороны. Эстония уделяет большое внимание территориальной защите, но ее фактические расходы не значительны, это видно из небольшого бюджета «Лиги обороны Эстонии», в сравнении с основным бюджетом министерства обороны. По нашему мнению, отказ от направления средств на создание надежной территориальной обороны можно рассматривать как решение

\footnotetext{
${ }^{30}$ V. Veebel and others, Territorial Defence, Comprehensive Defence and Total Defence...op.cit.
} 
перераспределения оборонных задач. «Союз защиты Эстонии» как гражданская организация получила определенные приоритеты в сфере выработки политики гражданской защиты Эстонии, но бюджетные ассигнования не следуют этому решению. Профессиональные вооруженные силы остаются единственными получателями постоянной финансовой поддержки своей деятельности ${ }^{31}$.

И в Литве, и в Латвии идея тотальной обороны или всеобъемлющей обороны противопоставляется доктрине классической, обычной обороне, и, хотя она упоминается в основных стратегических документах, таких как «Закон об основах национальной безопасности» и других официальных документах, данный подход все еще обсуждается в истеблишменте национальной безопасности и обороны Прибалтийских стран ${ }^{32}$. Дискуссии сводятся к главному вопросу о том, кто должен действовать в качестве основной «заинтересованной стороны» защиты государства - вооруженные силы или общество в целом, иди должны действовать на равных ${ }^{33}$.

Новому Литовскому парламенту и правительству Литвы придется принимать данное непростое политическое решение. Одни считают, что планы мобилизации - это планы национальной обороны и ничего более, другие утверждают, что национальная оборона - это дело всех государственных институтов и граждан, и Литве необходимо более эффективное межведомственное взаимодействие и более четкие процедуры в сфере обороны и защиты. Оборонная политика и готовность государства к войне - это задача всего общества, хотя военные несут ответственность за вооруженную защиту страны ${ }^{34}$. Планы национальной обороны не следует путать с планами вооруженной обороны государства ${ }^{35}$.

Одним из основных аспектов тотальной обороны является набор и подготовка резервных сил. Результаты опроса общественного мнения в 2016 году показали, что 68\% респондентов поддерживают восстановление обязательного призыва (Министерство национальной обороны Литовской Республики, 2016) ${ }^{36}$. Значительная и в настоящее время сокращающаяся доля призывников - добровольцы, их решение стать призывников основывается на получении финансовых и других льгот.

Для повышения устойчивости общества Прибалтийских стран необходимо решить основные политические и этические вопросы, с которыми сталкивается Литва как государство и общество. Социологическое исследование вопросов обороны и безопасности включали следующие вопросы: «Почему мне нужно защищать свою

\footnotetext{
${ }^{31}$ Estonian Defence League...op.cit.

${ }^{32}$ Lietuvos Respublikos mobilizacijos ir priimančiosios šalies paramos įstatymo Nr. I-1623 pakeitimo įstatymas, 2020 m. birželio 30 d. Nr. VIII -3228, Lietuvos Respublikos Seimas, https://e-seimas.lrs.lt/portal/legalAct/lt/ TAD/TAIS.33258/AHschKGAKp (03.11.2020).

${ }^{33}$ D. Šlekys, Lithuanian Military Transformation and Changing Efficiency Of Defence', [in:] Lithuania in the Global Context: National Security And Defence Policy Dilemmas, ed. G. Cesnakas, N. Statkus, Vilnius 2020, p. 307-325.

${ }^{34}$ Lithuanian National Defence Volunteer Forces, http://kariuomene.kam.lt/en/structure_1469/national_defence_volunteer_forces_1357.html (01.11.2021)

${ }^{35}$ Ibidem.

${ }^{36}$ Lietuvos Respublikos mobilizacijos...op.cit.
} 
страну?», «Что мы на самом деле защищаем?», «Мы все еще верим в демократию? Или мы видим в этом просто процедуру или декорацию?», «Какова более широкая миссия нашего общества /государства /Западного мира?» 37 .

Опросы общественного мнения предоставляют некоторую информацию о текущем состоянии социальной устойчивости в Литве. Уровень доверия к государственным институтам власти и учреждениям неоднозначен. С одной стороны, есть действительно высокий уровень доверия к институтам национальной безопасности, так, например, органам пожарной безопасности в 2020 году доверяли 87,1\% опрошенных, полиции - 66,2\%, вооруженным силам - 62,6\%, пограничной службе $-47,7 \%$. С другой стороны, доверие к основным политическим органам (за исключением канцелярии президента, которой доверяют более 48\%) и СМИ было очень низким: СМИ доверяли $36,2 \%$, правительственным учреждениям - 28,3\%, судебной власти $-25,4 \%$, парламенту - $13 \%$ и политическим партиям $-6,4 \%{ }^{38}$.

В соответствии с результатами опроса населения Латвии, проведенному в 2017 году, 36\% респондентов в случае войны поддержали бы гражданское сопротивление, а 22\% присоединились бы к вооруженному сопротивлению, $3 \%$ респондентов сами организовали бы акции гражданского сопротивления ${ }^{39}$. В 2020 году были представлены результаты еще одного исследования восприятия литовскими гражданами международной политики и угроз. Результаты показали, что $32 \%$ будут готовы присоединиться к вооруженной обороне, что аналогично ситуации, сложившейся в 2018 году ${ }^{40}$.

\section{ЗАКЛЮЧЕНИЕ}

В заключении следует отметить схожесть политических подходов всех Прибалтийских стран к планам оборонной политики и безопасности. Эстония следует подходу тотальной обороны с акцентом на защиту территории, обязательность военной службы и наличие армии резервистов. С начала 2000-х Эстония не отказалась от принципа территориальной обороны, и наряду с членством в НАТО, сосредоточила внимание на развитии независимого оборонного потенциала страны.

Защита территории и комплексная оборона страны играют решающую роль в обеспечении доверия общества к доктрине национальной обороны и сдерживанию. В Эстонии данные подходы рассматриваются как важные элементы национальной

37 Public opinion and market research, 2020, http://www.vilmorus.lt/index.php?mact=News,cntnt01,detail, $0 \&$ cntnt 01 articleid $=2 \&$ cntnt01 returnid= $=20(08.10 .2021)$

${ }^{38}$ Ibidem.

${ }^{39}$ A. Ramonaitè and others, Kas eitu ginti Lietuvos? Pilietinio pasipriešinimo prielaidos ir galimybès, Vilinius 2018, p. 200.

${ }^{40}$ L. Kojala and others, Geopolitikos ir tarptautinès politikos bei grèsmiu suvokimo tyrimas, Rytų Europos studiju centras/Eastern Europe Studies Centre, Vilnius 2020, https://www.eesc.lt/wp-content/uploads/2020/07/RESC-tyrimas.pdf (06.10.2021). 
системы обороны на ранних этапах гибридного конфликта. Соответственно, существует национальный консенсус в отношении необходимости развития потенциала территориальной обороны и требования о выделении надлежащих ресурсов.

Обозначилась еще одна проблемная сфера - уровень сотрудничества между балтийскими соседями. Это означает определенные затруднения при единстве подходов и осуществления территориальной защиты. Следует признать, что «Союз обороны Эстонии» и аналогичные ему организации в Латвии и Литве, провели общие учения и организуют сотрудничество, при отсутствии правовых основ для подобного сотрудничества, соответствующих общих механизмов и процедур планирования.

В условиях возможного военного конфликта границы между странами Балтии не будут играть существенной, функциональной роли, и отсутствие правовой основы сотрудничества может воспрепятствовать попыткам территориальной защиты. Это является важным фактором для развертывания регулярных вооруженных сил и для повышения эффективности оперативных возможностей. Силы территориальной обороны должны быть готовы к действию в условиях ограниченности боевого потенциала, низкого уровня психологической подготовки; но они будут играть определяющую роль в активном и пассивном сопротивлении. Данная составляющая политики обороны и безопасности важна для малых стран как часть стратегии сдерживания, препятствующей агрессии.

Однако необходимые дискуссии не будут ограничиваться данными подходами, поскольку современные общества развиваются и восприятие угроз меняется. Например, в Эстонии угроза «широкомасштабного или ограниченного военного нападения на Эстонию» в октябре 2018 года была поставлена респондентами на 7-ое место по вероятности наступления события (20\% положительных ответов; довольно невероятно $47 \%$ респондентов; совершенно невероятно 24\% $)^{41}$. Основными угрозами для национальной безопасности респондентами были названы кибератаки, «фейковые новости» и вмешательство в «политику или экономику Эстонии с целью повлиять на них в собственных интересах».

Таким образом восприятие угроз и рисков современных обществ стран Прибалтики меняется так же как и изменяются потребности обществ. Важным становится готовность противостоять невоенным угрозам, именно в этом должна заключаться миссия современной доктрины обороны государства. Уже существуют законы, позволяющие оперативно реагировать на более низких уровнях системы государственного управления. Эстония уже решила адаптировать свои силы территориальной обороны к новым угрозам, внося ряд изменений в их функционирование, в зависимости от условий на местах в каждом конкретном случае.

\footnotetext{
${ }^{41}$ J. Kivirähk, Public Opinion and National Defence...op.cit. 


\section{ЛИTEPATУPA [LITERATURA]}

\section{ПРАВОВЫЕ АКТЫ [PRAVOVYE AKTY]}

Доктрина информационной безопасности РФ, Совет Безопасности Российской Федерации (scrf.gov.ru) (25.11.2021) [Doktrina informatsionnoj bezopasnosti RF, Sovet Bezopasnosti Rossijskoj Federatsii] In scrf.gov.ru.

Lietuvos Respublikos Seimas. (2020a). Lietuvos Respublikos mobilizacijos ir priimančiosios šalies paramos įstatymo № I-1623 pakeitimo įstatymas, $2020 \mathrm{~m}$. birželio 30 d. № VIII 3228. Lietuvos Respublikos Seimas In https://e-seimas.lrs.lt/portal/legalAct/lt/ TAD/TAIS.33258/AHschKGAKp (08.10.2021).

Lietuvos Respublikos Seimas. (2020b). Lietuvos Respublikos karo padèties įstatymo № VIII 1721 pakeitimo ịstatymas, $2020 \mathrm{~m}$. birželio $30 \mathrm{~d}$. № XIII-3229 In https://e-seimas.lrs.lt/portal/le-

galAct/lt/TAD/6ba742c0c0ec11 eaae0db016672cba9c?jfwid=n3y3g01as (01.11.2021).

Стратегия национальной безопасности РФ [Strategiya natsionalnoj bezopasnosti], In scrf.gov.ru.

Военная доктрина РФ [Voennaya doktrina FR] In scrf.gov.ru, scrf.gov.ru.

\section{МОНОГРАФИИ [MONOGRAFII]}

Ramonaitė Ainè, Skirkevičius Paulius, Vosylius Eugenijus, Petronyte-Urbanavičienė. 2018. I. Kas eitų ginti Lietuvos? Vilnius: Aukso žuvys.

\section{ГЛАВА В МОНОГРАФИИ [GLAVA V МONOGRAFII]}

Šlekys Deividas 2020. Lithuanian Military Transformation and Changing Efficiency Of Defence In Lithuania in the Global Context: National Security And Defence Policy Dilemmas, 307-325. General Jonas Žemaitis Military Academy of Lithuania.

\section{НАУЧНЫЕ ЖУРНАЛЫ [NAUCHNYJE ZHURNALY]}

Atmante Kristine 2020. "Comprehensive defence in Latvia - rebranding state defence and call for society's involvement”. Journal on Baltic Security 6(2): 1-15.

Clemmesen Michael. 2000. "Territorial Defence in Baltic Defence College". The Baltic Defence Review №3.

Graube Raimonds. 1999. “The Latvian Armed Forces Today”. Nato's Nations and Partners for Peace. Special Issue: 63-68.

Jakubczak Ryszard. 2016. „Wojska Obrony Terytorialnej w sztuce wojennej”. Ante Portas Studia nad Bezpieczeństwem. № 2(7): 23-44.

Laaneots Ants. 2000. "The Defence League and Defence Districts". The Baltic Defence Review № 3: 87-92

Maskaliunaite Asta. 2020. "Editorial Introduction: Special Issue on Understanding of Total Defence in the Baltic Countries". Journal on Baltic Security 6(2): 1-2.

Statkus Nortautas, Paulauskas Kęstutis. 2006. "Foreign Policy of Lithuania: Linking Theory to Practice”. Lithuanian Foreign Policy Review 17: 41-82. 
Veebel Viljar, Ploom Illimar, Vihmand Liia, Zaleski Krzystof. 2020. "Territorial Defence. Comprehensive Defence and Total Defence: Meanings and Differences in the Estonian Defence Force". Journal on Baltic Security 6(2): 1-13.

\section{ИНТЕРНЕТ-ИСТОЧНИКИ [INTERNET-ISTOCHNIKI]}

Estonian Defence League. 2019 In http://www.kaitseliit.ee/en/edl.

Estonian Ministry of Defence 2008. Yearbook of Estonian Ministry of Defence. 2008. Milterm: Comprehensive Approach. Yearbook 2008/2009. Ministry of Foreign Affairs In vm.ee.

Estonian Ministry of Defence. 2010. Strategy of State Defence In http://www.kaitseministeerium.ee/sites/default/files/elfinder/article_files/riigikaitse_strateegia_2010_0.pdf .

Estonian Ministry of Defence. 2018. National Defence Action Plan 2019-2022. Tallinn updated 22 February 2018 In http://www. kaitseministeerium.ee/en/objectives-activities/defenceplanning/national-defence-action-plan-2019-2022.

Flanagan Stephen J. et al. 2019. Deterring Russian Aggression in the Baltic States through Resilience and Resistance. RAND Corporation In https://www.rand.org/pubs/research_reports/RR2779.html.

Jermalavičius Tomas, Pernik Piret, Hurt Martin, Breitenbauch Henrik, Järvenpää Pauli. 2014. Comprehensive Security and Integrated Defence: Challenges of implementing whole- ofgovernment and whole-of-society approaches (ICDS Report). International Centre for Defence Studies In https:// www.digar.ee/arhiiv/et/download/200632.

Kivirähk Juhan. 2018. Public Opinion and National Defence, Survey. Ministry of Defence. In https://kaitseministeerium.ee/sites/default/files/elfinder/article_files/public_opinion_and_national_defence_2018_october_0.pdf.

Kojala Linas., Kulys Justinas, Prochorenko Andrius, Roževič Adam, Jastramskis Mažvydas. 2020. Geopolitikos ir tarptautinès politikos bei grèsmių suvokimo tyrimas. Rytų Europos studijų centras/Eastern Europe Studies Centre In https://www.eesc.lt/wp-content/uploads/2020/07/ RESC-tyrimas.pdf.

Latvian National Guard. 2019 In https://www.zs.mil.lv/en.

Lithuanian National Defence Volunteer Forces, http://kariuomene.kam.lt/en/structure_1469/national_defence_volunteer_forces_1357.html.

Malinionis Vaitodas. 2020. Vaidotas Malinionis: Lietuviška saviapgaulès išraiška In https://www.15min.lt/naujiena/aktualu/nuomones/vaidotas-malinionis-lietuviskasaviapgaules-israiska-18-1403096.

NATO. Supreme Headquarters Allied Power Europe. 2010. Allied Command Operations Comprehensive Operations Planning Directive COPD Interim v 1.0 In https://info.publicintelligence.net/NATO-COPD.pdf.

Šlekys Devidas. 2020. Nauji / seni gynybos politikos namų darbai. LRT In https://www.lrt.lt/naujienos/nuomones/3/1281401/deividas-slekys-nauji-seni-gynybospolitikos-namu-darbai?fbclid=IwAR2uJFnMQc7y0U3QBUSb4npivpp3hipdl Dvu_XZgN3gjYKBns4prt1XazmE.

Szymański Piotr. 2015. The Baltic states' Territorial Defence Forces in the face of hybrid threats. Commentaries OSW. Centre for Eastern Studies (OSW). Warsaw № 165, 19 
March/2015, p. 1-6 In https://www.osw.waw.pl/en/publikacje/osw-commentary/201503-20/baltic-states-territorial-defence-forces-face-hybrid-threats.

Vilmorus. 2020. Public opinion and market research. In: http://www.vilmorus.lt/index.php?mact=News,cntnt01, detail,0\&cntnt01 articleid=2\&cntnt01 returnid=20. 